\title{
Library Peer Evaluation For Promotion and Merit Increase: How It Works
}

\begin{abstract}
Library peer evaluation for promotion and special merit increase was introduced at the Bouillon Library in the 1971-72 academic year. The evaluations, in addition to reinforcing the dean of library services' recommendations, revealed how the librarians rated each other by department, position, and sex.
\end{abstract}

C

Aentral Washington State College is a liberal arts and teacher-training college, with 7,000 students and 380 faculty members. Central's Bouillon Library houses both the audiovisual library and the traditional printed library. Central's librarians were granted faculty status in 1954. In 1962, librarians including media professionals were granted full faculty status. As the M.A.L.S. degree was recognized as the terminal degree for librarians in 1971, most were eligible for promotion.

In the 1971-72 academic year, Bouillon Library had twenty-one library faculty members and forty-five civil service employees. The library's faculty was divided into three divisions, Audiovisual, Public Service, and Technical Service. Each division was headed by an assistant director who reported to the dean of library services. Among the twenty-one library faculty members, there were one professor, five associate professors, twelve assistant professors, and three in-

Mr. Yen-Ran Yeh is assistant professor of librarianship and head, Cataloging Department, Central Washington State College, Ellensburg, Washington.

structors. All library faculty had master degrees; three had doctorates, five had second master degrees, and one was an $\mathrm{ABD}$.

A five-page faculty evaluation form, developed in 1968-69 was previously used to evaluate library faculty for reappointment, promotion, special merit increase, and tenure. This was the first time that Bouillon Library faculty had used a peer-evaluation system. A Personnel Committee was elected in the 1971 -72 academic year, consisting of four members, one representing each of the three divisions and a fourth one elected at large. ${ }^{1}$ The Personnel Committee was instructed by the dean of library services to revise the old evaluation form, which had taken much time to process. After several weeks of deliberation, the Personnel Committee presented a new one-page evaluation form which was adopted by the library faculty. (See Appendix)

During the fall quarter, each library faculty member was asked to fill out a professional service record with his latest achievements in working effectiveness, scholarship and productivity, special services to library and college, and professional activities. This record was 
attached to the faculty evaluation forms and served as the basis for peer evaluation. The Personnel Committee sent evaluation forms to each library faculty member on January 31, 1971. Each member had two weeks to complete the evaluation forms for his peers. After the Personnel Committee received all the evaluation forms, the committee secretary compiled a summary rating sheet for each faculty member.

The Personnel Committee met on February 17, 1972 with the dean of library services, a nonvoting member, since the dean, according to Library Personnel Committee guidelines, serves as an ex-officio member of the Personnel Committee. Each committee member and the dean read all the evaluations, except those forms for himself; no faculty, including the committee members, would discover how his peers evaluated him.

The committee evaluated each faculty member to determine promotion and special merit increase. When a committee member was being evaluated, the member would leave the room. The committee recommended eleven library faculty for promotion: two to full professor, six to associate professor, and three to assistant professor. In addition, seven library faculty were recommended for special merit increases.

The committee later wrote a letter summarizing the recommendations, which all four members signed, and sent it to the vice-president for academic affairs with copies to the dean and each committee member.

The dean of Library Services forwarded his own independent recommendations to the vice-president for academic affairs. The dean recommended eight library faculty for promotion: two to full professor, four to associate professor, and two to assistant professor. The dean also recommended five faculty for special merit increases with the provision that those not promoted be considered for merit. The eight faculty recommended for promotion by the dean were also recommended by the committee. The dean's special merit-increase list (subsequently increased to twelve) included all faculty recommended by the committee and more.

The dean defended each case for promotion to the College Committee on Promotion at its March 8 session, with assistance from the Personnel Committee chairman. On the basis of the College Committee's decisions, the vice-president for academic affairs recommended to the president six library faculty for promotion. The president then recommended the nominees to the Board of Trustees who approved the promotions. In all, five library faculty were promoted: one to professor, two to associate professor, and two to assistant professor.

All five faculty promoted were recommended by both the dean and the Personnel Committee. Three library faculty recommended by both the dean and the committee were not promoted. Three faculty recommended by the committee but not by the dean also failed to be promoted. Recommendations of both the dean and the Personnel Committee were necessary, although no guarantee to promotion.

The dean later compiled a priority list of special merit increases. As the library's fund could only provide five half steps of merit increase, only the top five faculty on the list received this increase. $^{2}$

The evaluation forms showed that the library faculty tended to endorse promotion more favorably than special merit increase: they cast 51.93 percent yes votes for faculty promotion, and 37.53 percent yes votes for special merit increase (which had been null the previous year). ${ }^{3}$

One delicate point of peer evaluation is evaluation of supervisors by nonsu- 
pervisors. The supervisor here is a library faculty who supervises one or more library faculty (this does not include supervision of civil-service employees). Supervisors eligible for promotion received 69.05 percent yes votes from nonsupervisors, as compared with 51.93 percent yes votes from all library faculty. Nonsupervisors seem to strongly endorse the promotion of their supervisors.

As for special merit increase for supervisors, nonsupervisors cast 33.33 percent yes votes, which is below the 37.73 percent total library average. Nonsupervisors tended to recommend either promotion or special merit increase to supervisors, but not both. Thus, because the majority of nonsupervisors recommended supervisors for promotion, the percentage of positive special merit increase votes for supervisors was relatively lower.

Perhaps reflecting the women's liberation movement, and the fact that fe- male librarians' salaries are generally lower than those of male librarians, female faculty cast 52.78 percent yes votes for female faculty special merit increases, as compared with $\mathbf{4 2 . 4 2}$ percent yes votes for male faculty increases.

Ironically, however, because female faculty held fewer advanced degrees beyond M.A.L.S. and listed fewer scholarly activities, female faculty cast only 50 percent yes votes for female faculty promotion and 32.81 percent no votes as compared with 58.73 percent yes votes for male faculty promotion and $\mathbf{1 5 . 8 7}$ percent no votes. This points out one dilemma for the female library faculty. Although they want equal job opportunity and equal pay, unfortunately, they are handicapped by being less prepared than the male faculty.

The three divisions of the library, Audiovisual, Technical Service, and Public Service, evaluated each other. A summary of the results are shown in Tables 1 and 2.

TABLE 1

Recommendations for Promotion

\begin{tabular}{lllr}
\hline \hline & \multicolumn{1}{c}{ Yes } & \multicolumn{1}{c}{ No } & Abstain \\
\hline$\quad$ Public Service candidates: & & & \\
Votes from Audiovisual division & $64.58 \%$ & $31.25 \%$ & $4.17 \%$ \\
Votes from Technical Service division & $53.19 \%$ & $19.15 \%$ & $27.66 \%$ \\
$\quad$ Audiovisual candidates: & & & \\
Votes from Public Service division & $75 \%$ & $0 \%$ & $25 \%$ \\
Votes from Technical Service division & $66.66 \%$ & $16.67 \%$ & $16.67 \%$ \\
$\quad$ Technical Service candidates: & $20 \%$ & $66.67 \%$ & $13.33 \%$ \\
Votes from Audiovisual division & $35 \%$ & $42.5 \%$ & $22.5 \%$ \\
Votes from Public Service division & & \\
\hline
\end{tabular}

TABLE 2

RECOMMENDATIONS FOR MERIT INCREASES

\begin{tabular}{llll}
\hline \hline & \multicolumn{1}{c}{ Yes } & No & Abstain \\
\hline$\quad$ Public Service candidates: & & & \\
Votes from Audiovisual division & $27.08 \%$ & $22.92 \%$ & $50 \%$ \\
Votes from Technical Service division & $33.3 \%$ & $27.1 \%$ & $39.6 \%$ \\
$\quad$ Audiovisual candidates: & $43.75 \%$ & $12.5 \%$ & $43.75 \%$ \\
Votes from Public Service division & $27.78 \%$ & $25 \%$ & $44.22 \%$ \\
Votes from Technical Service division & $13.33 \%$ & $36.67 \%$ & $50 \%$ \\
$\quad$ Technical Service candidates: & $35 \%$ & $27.5 \%$ & $37.5 \%$ \\
Votes from Audiovisual division & & & \\
Votes from Public Service division & &
\end{tabular}


The Audiovisual division received the most favorable endorsement for promotion and merit increase by the other two divisions. Central Washington State College has a strong Audiovisual division, both in quality of faculty and service which might have affected this favorable vote. Technical Services received the least for promotion and merit increase, perhaps because of the nature of technical service work.

Another observation from this study is that promotion from instructor to assistant professor is almost automatic after a person has served five years in the instructor rank. The higher the rank, the more difficult is promotion. The rank of professor is the most difficult to achieve.

Peer evaluation, as demonstrated at the Bouillon Library, allowed every library faculty member a chance to participate in management. Rather than diminishing the dean of library services' authority in recommending promotion and special merit increase, peer evaluation served to strengthen his recommendations. The dean could base his recommendations on peer information and vote. Library faculty opinion and the dean's judgement overlapped. Peer eval- uation took more time, but as a result the Bouillon Library received the highest number of promotions among all departments in the 1971-1972 academic year. A longer period of study would be essential, however, for confirmation of the results of peer evaluation.

\section{REFERENCES}

1. The author was elected chairman of the committee.

2. In the past, all evaluation forms were destroyed each year after the College Committee had acted upon all of the recommendations. In the 1971-1972 academic year, upon the author's request, it was decided by library faculty that the author be authorized to keep all evaluation forms except his own for further study. He was asked to make the results available to the library faculty that they might better understand the peer evaluation procedure and could improve the procedure for next year.

3. There were a substantial number of abstentions. Normally, if a faculty member received a majority of yes votes, a few abstentions and no votes would not count against him. However, if he received a large number of abstentions, then his yes votes would be reduced, and his chance to be recommended for promotion and special merit increase would be relatively lower. Therefore, to a certain degree, abstentions are unfavorable votes.

APPENDIX

Sample Evaluation Form

DEPARTMENT

EVALUATION AND RECOMMENDATION FOR

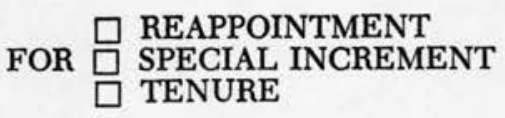

\section{PROMOTION TO $\square$ PROFESSOR ASSISTANT PRO}

To be completed by all Library faculty members and forwarded to the vice-president for academic affairs via the Personnel Committee.

The following criteria are to be used in making a decision. Each person is asked to evaluate frankly and objectively each criterion. " 1 " is low with " 9 " the highest rating. N stands for no basis for judgment.) You may prefer to comment on the reverse instead of using the rating.
1. Teaching and/or professional effectiveness.
$\begin{array}{llllllllll}1 & 2 & 3 & 4 & 5 & 6 & 7 & 8 & 9 & \mathrm{~N}\end{array}$ 
2. Scholarship and productivity.

3. Personal qualities (degree to which person exhibits character and personality traits that command respect of associates).

4. Special services (acceptance and fulfillment of department and college assignments).

5. Professional activities and public services (community, state, or national).

6. Overall rating of competence of the faculty member.

\section{REAPPOINTMENT}

I recommend reappointment.

I do not recommend reappointment.

SPECIAL INCREMENT

I recommend a special (merit) salary increment.

I do not recommend a special (merit) salary increment.

TENURE (Only tenured faculty recommend on tenure)

I recommend tenure.

I do not recommend tenure at this time.

PROMOTION

$\square$ I recommend promotion to

I do not recommend promotion at this time.

COMMENTS (may use reverse side):

Signature $\begin{array}{llllllllll}1 & 2 & 3 & 4 & 5 & 6 & 7 & 8 & 9 & \mathrm{~N}\end{array}$

$\begin{array}{llllllllll}1 & 2 & 3 & 4 & 5 & 6 & 7 & 8 & 9 & \mathrm{~N}\end{array}$

$\begin{array}{llllllllll}1 & 2 & 3 & 4 & 5 & 6 & 7 & 8 & 9 & \mathrm{~N}\end{array}$

$\begin{array}{llllllllll}1 & 2 & 3 & 4 & 5 & 6 & 7 & 8 & 9 & \mathrm{~N}\end{array}$ 